\title{
Views of university instructors and students on English as a Lingua Franca (ELF) and World Englishes (WES)
}

\author{
İrfan Tosuncuoğlu ${ }^{a} *$ (iD), Özkan Kırmızı b (D) \\ ${ }^{a}$ Karabuk University, Karabuk, Turkey \\ ${ }^{b}$ Karabuk University, Karabuk, Turkey
}

\section{APA Citation:}

Tosuncuoğlu, İ. \& Kırmızı, Ö. (2019). Views of university instructors and students on English as a lingua franca (ELF) and World Englishes (WES) Journal of Language and Linguistic Studies, 15(1), 158-173.

Submission Date:04/01/2019

Acceptance Date:06/02/2019

\begin{abstract}
The rapid proliferation of English as a medium of communication has sparked large-scale debate on the role of English and the terminology such as ELF, WE, EIL, etc. The paradigms of English as a Lingua Franca (ELF) and World Englishes (WEs) are sometimes considered to be confusing to differentiate between, and in addition these terms are often used interchangeably. In order to obtain the perceptions of the instructors and students towards ELF and WEs, a questionnaire was implemented in a state university. The questionnaire consisted of both closeended and open-ended questions. The participants were 44 English Instructors and 104 students of the English Language and Literature Department. The instructors of English ranged in age between 23 to 51 and the students were aged 18 to 25 . The total number of participants was 148 . Most of the participants stated that they want to sound like a "native speaker" and it would not be productive to have phonological or syntactic local varieties of English.
\end{abstract}

(C) 2019 JLLS and the Authors - Published by JLLS.

Keywords: World Englishes; English as a Lingua Franca; learning; language teaching

\section{Introduction}

English has gained a new role in the early twenty-first century as a requisite of the globalising world. Although the proliferation of globalisation has made a dramatic impact on all the dimensions of the lives of individuals, it might not have been possible for globalisation to achieve such a status without a common language establishing interaction and communication between people. This language is undoubtedly English. Along with the proliferation of globalisation, the role of English as an international language has changed remarkably.

Although the statistics exhibit variances, English is being used by billions of people on a global scale (Graddol, 2006; Tosuncuoğlu, 2017) and the number of people who speak English is also on the increase. The rapid proliferation of English as a medium of communication has sparked a large-scale debate on the position of English with its terminology used in order to define different concepts in the

\footnotetext{
* Corresponding author. Tel.: +0506 2914108

E-mail address: irtosun@yahoo.com
} 
language. The notions of 'EIL - English as an International Language' as well as 'English as a Global Language' (Crystal, 2003), 'ELF - English as Lingua Franca' (Jenkins, 2003), 'English as a World Language' (Mair, 2003), 'WE - World English' (Brutt-Griffler, 2002) and 'English as a Tool of Intercultural Communication' (Seidlhofer, 2003) have been utilised as umbrella terms denoting the use of English within the contexts of the 'Inner Circle', 'Outer Circle' and 'Expanding Circle' (Kachru, 1985, 1996). The conventional definition of EIL encompasses the use of English for domestic communication within countries as well as within the scope of and in between Kachru's 'Circles' Kachru's (1985, p. 12) three circles model as shown below;

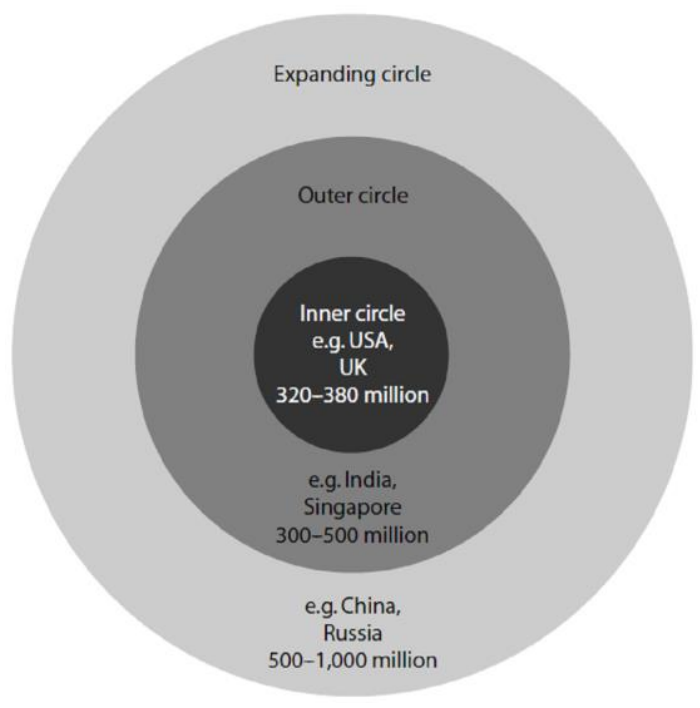

Figure 1. The "three circles of English"

However, when English is chosen as the medium of communication between people from different native language environments and who are separated by lingua-cultural boundaries, the term of preference is 'English as an International Language (EIL)' or 'English as a Lingua Franca (ELF)' (House, 1999). There is a common conviction among scholars that there is not a great difference between the terms EIL, ELF, or World Language and that these are different indicators attributed to the current role of English. According to Jenkins (2017), the first uses of (versions of) the term 'English as a Lingua Franca' occurred in the 1980s were by two German scholars, Hüllen, and Knapp. Flowerdew (2015) points out that one of the initial definitions of ELF was put forth by Firth (1996; cited in Seidlhofer, 2004) as follows: "ELF is a 'medium of communication' among people who neither share a common mother tongue nor a common (national) culture and for whom English is the chosen foreign language". As it has most of the properties mentioned above, EIL is being used as an alternative to the term 'English as a Lingua Franca (ELF)'. Seidlhofer (2003) uses the terms 'English as a Global Language', 'English as a Lingua Franca (ELF)' and 'English as an International Language (EIL)' interchangeably. Mesthrie and Bhatt (2008) defines EIL as a general term signifying the use of English among speakers from different countries whose mother tongues are not originally English.

In addition to this, Sharifian (2009) points out the difference between 'International Language' and 'EIL' and acknowledges that the uses in which the word 'English' is modified by an adjective calls to mind a specific variety of language such as American English, Singaporean English or Chinese English. Therefore, the concept of an 'International Language' may indicate a specific variety of English and this is entirely different from what is meant by the term EIL. This is why EIL rejects the idea of a specific variety of language. Sharifian defines the 'EIL contexts' as contexts in which English is used between speakers coming from different cultural and national backgrounds. Instead of terms such as 'English 
speakers coming from different cultural and national backgrounds', he uses the term 'World Englishes (WEs) speakers'.

Jenkins (2007) prefers using the term ELF instead of EIL because she believes that the terms International English and EIL should only correspond to the English of speakers for whom it is their mother tongue, and which is significantly different from the varieties of English that are used across the globe. In her project called 'VOICE', Seidlhofer (2013) favours the term ELF over EIL and defines EIL as corresponding to the most widespread contemporary use of English worldwide. For this reason, as put forth by Seidlhofer (2011), it is determined that ELF is a more suitable term for reflecting the differences in the varieties of English and for our use in this paper.

Because it draws from such a global role of English, analysing the 'English as a Lingua Franca (ELF)' theory in detail is an important necessity, and since the widespread use of English plays a significant role with regard to ELF, it is necessary to underscore the changing status of English. Since English teaching and learning may not be compatible with the standard norms, ELF also aims to provide a perspective for foreign language teachers and students in this area (Dewey \& Patsko, 2017).

\subsection{Related Issues, Literature and Terms}

The arguments on the notions of "World Englishes (WEs)" and "Standard English (SE)" were first put forth by Quirk (1985) and Kachru (1985, 1992). In these arguments, Quirk (1990) supported Standard English (SE) and emphasizes that a single common standard needs to be adopted in the use of English within all presumable contexts. He suggests that English might lose own status and role as the international language due to the new varieties that are not mutually intelligible and recommends that English teachers use native speaker norms and native-like performance as a basis. Moreover, Standard English provides a plethora of different functions such as serving as a common language for the majority of students who receive education abroad. The effect of the experiences from receiving education abroad on foreign language students and the differences between the environments of learning abroad and in their home countries has increasingly received more attention and this subject has become the focus of much interest over the last twenty years (Collentine \& Freed, 2004; Kinginger, 2008; Jenkins, Cogo, \& Dewey, 2011; Kirkpatrick, 2010). While some of these studies define Standard English as a tool of intercultural communication, others call it 'English as an International Language'. Seidlhofer (2005), who is one of the significant scholars involved in this series of studies, defines ELF as a tool for communication between individuals coming from different native language backgrounds. Furthermore, Jenkins (2009) emphasises that speakers coming from different lingua-cultural backgrounds and whose native languages are not English (NNSs/Non-Native Speakers), use English as a common medium of communication (Lingua Franca).

Furthermore, Kachru (1985) states that native language norms are not compatible with the reality of sociolinguistics within the contexts where English is utilized. Kachru underscores that speakers whose native language is English (NSs - Native Speakers) appear to be losing the sole ownership of this language in terms of controlling its standardisation; in effect, native speakers have become a minority and the reflections of this socio-linguistic reality needs to be acknowledged. In order to be able to perceive the linguistic creativity and differences emerging in multi-lingual circumstances, new paradigms, perspectives and critical pedagogies are needed (Kachru, 1985; cited in Deniz et al., 2016). In addition to this, earlier researchers have proposed that the idea of "the ownership of English by its native speakers (NSs)" was being questioned, as English is a language that can be used with innumerable variety of accents and dialects in different countries all across the globe.

What constitutes the basis for the efforts of classification mentioned above, is the fact that English is the only hyper-central language which has been used all over the world in a diverse and extensive series 
of functions over a long period of time (Cook, 2008). As understood from the abundance of researchers working on it, the leading classification is WEs (World Englishes), which has deserved to be more closely examined in recent times (Mesthrie \& Bhatt, 2008). Among the various models facilitating the comprehension of the concept of 'WE' by illustrating the diversity of English, Kachru's model mentioned above, is commonly held as the most comprehensible one.

Kachru (1985) modelled the socio-linguistic profile of English by separating English speaking communities into three concentric circles: the inner circle; the outer circle; and the expanding circle. The inner circle encompasses the countries in which English is spoken as a native language (ENL English as a Native Language) such as the United Kingdom and Canada. The outer circle encompasses the countries that are the former colonies of the USA and the United Kingdom and in which English plays an important second language role (ESL - English as a Second Language) in multi-lingual environments such as Malaysia, Singapore and India. The expanding circle encompasses the regions where English is learned, taught and used as a foreign language (EFL - English as a Foreign Language). Greece, Turkey and Poland are some of the examples for such countries. Since the outer and expanding circles share many properties, it is not as easy as it has been in the past to make an absolute demarcation between them.

Using various terms such as nativised varieties, acculturation (adoption of the culture) and indigenisation, Kirkpatrick (2007) articulates the idea that "the variety of English which is nativised, acculturated and indigenised is one that is affected by the local cultures in and around which it developed." For this reason, it is unavoidable to realise that English does not solely comprise the 'conventional' language varieties such as British, American and Australian English but that it also comprises varieties such as Singaporean, Malaysian and Indian English.

On the perspectives concerning the WEs mentioned above, both of the linguists have received criticism from scholars (Lowenberg, 2002; Bamgbose, 1998), who consider WEs an all-encompassing term indicating the increasingly emerging varieties of English, not only within the scope of the outer circle but of the inner and expanding circles as well. Exactly at this point, WE deviates from EIL, a recently emerged notion. Although EIL is similar to WEs in terms of taking all nativised language varieties into consideration, it does not take the circles into account (Jenkins, 2009).

Already established as the first world language used in tourism, trade, negotiation and science, English is characterised as 'an international language' due to its connection with individual countries and cultures (Paradowski, 2008). This is a more extensive concept as opposed to WE in terms of English being used as a more comprehensive medium of communication in both the outer and expanding circles (McKay, 2002: 38). Brutt-Griffler (2002), who attributes this state of affairs to the acquisition of English at the macro level and shares the views of Smith (1976; cited in McKay, 2002: 12) and Canagarajah (2005: 23), draws attention to both the local and global presence of English.

The concept of EIL needs to be narrowed down, as it currently symbolises an environment in which the speakers' identities and purposes of using English is remarkably interwoven and extensive. In line with this aim, Brown (2012) qualifies WE and raises awareness concerning the reality of "different legitimate varieties of English existing outside of the local dialects needing to be recognised by ESL/EFL students" as the first option to constrain the scope of EIL.

As mentioned earlier, the discussions concerning WE and ELF have led to the emergence of multitudinous discrepancies and critical questions concerning student/teacher education and the agenda of foreign language learning/teaching. Although some scholars are well aware of ELF and its reflections on ELT (Alptekin, 2002; Bayyurt, 2008; İnceçay \& Akyel, 2014), there are few empirical studies on this subject, and we have aimed to discover the perceptions of students on ELF and WEs within the bounds of our knowledge of ELF and WEs. Accordingly, this research was performed in order to obtain 
awareness from the instructors and undergraduate students in a state university with respect to ELF and WEs.

\subsection{Research questions}

In order to get overall responses to the following questions, an experiment was designed;

1. What are the perceptions of Instructors and students with respect to the concepts of EFL and WEs?

2. What are the perceptions of Instructors and students towards the ownership of the English Language in the world (or should the ownership belong to the any of the other languages)?

3. Are there any statistically significant differences in the viewpoints of the participants in terms of gender and profession?

\section{Method}

\subsection{Sample / Participants}

The study was conducted with 44 English Instructors of English (21 male, 23 female) and 104 students from the English Language and Literature Department (39 male, 65 female). Students were aged between 18 and 25 (M:21.5) and Instructors of English in the age range of 23 to 51 (M:37). The student participants were undergraduate students majoring in English Language and Literature. The instructors consisted of two groups; the first group teach English as a Foreign Language for the other departments such as Engineering, Medicine, Science Faculty, etc., in addition to their majors. The second group of instructors teach English at Preparatory School. Preparatory schools exhibit the characteristic of serving as a transitional period for students into the actual academic life in a university. Within this period of one (or two) years, students have the opportunity to improve their English language levels as well as get to know the university life and their departments. Before the instructors and students responded to the questionnaire, they were provided with a detailed explanation of World Englishes and English as a Lingua Franca and some related issues.

Table 1. Descriptive statistics about the participants

\begin{tabular}{|c|c|c|c|c|}
\hline & & \multicolumn{2}{|c|}{ Gender } & Total \\
\hline \multirow{4}{*}{ profession } & & male & female & \\
\hline & Instructor & 21 & 23 & 44 \\
\hline & Student & 39 & 65 & 104 \\
\hline & Total & 60 & 88 & 148 \\
\hline
\end{tabular}

\subsection{Instrument $(s)$}

The present study is a quantitative study depending on survey. In order to collect data, a questionnaire, adapted from $\mathrm{He}$ (2015), was used. The questionnaire contains three parts. The first part collects data about the demographic properties of the participants, the second part includes 5-point Likert type items (15 items), and the third part asks a number of open-ended questions to the participants. The answers participants provided for the Likert part range from 1 (I don't agree at all) to 5 (I completely agree). Descriptive statistics and T-test were run in order to analyze data. All statistical analyses were 
performed with the IBM SPSS Statistics 23.0 (Armonk, New York). The open-ended section includes 6 questions. The open-ended questions are as follows:

(1) What are your views about the native speaker and non-native speaker teacher dilemma (dichotomy). Which one is better for teaching / learning purposes?

(2) What can you say about the knowledge of ELF (English as common Language) and EFL (English as a Foreign Language)?

(3) Do you have any knowledge of Standard English or World Englishes (English as common Language)?

(4) What do you know about the cultural aspects in language teaching?

(5) Do you believe in the ownership of English Language in the world or should the ownership belong to any of the other languages?

\section{Results}

In the first place, the findings are presented as descriptive statistics. The mean scores and standard deviations are given in Table 2.

Table 2. Descriptive Statistics of terms (items) in questionnaire

\begin{tabular}{|c|c|c|c|c|c|}
\hline items & $\mathbf{N}$ & mi & $\max$ & $\mathbf{M}$ & Sd \\
\hline 1. I have heard of world Englishes. & 147 & 1 & 5 & 3.76 & 1.149 \\
\hline $\begin{array}{l}\text { 2. British English and American English are the major varieties of English used } \\
\text { in our textbooks. }\end{array}$ & 147 & 1 & 5 & 4.10 & 0.905 \\
\hline $\begin{array}{l}\text { 3. We should adopt a native-speaker model of English (e.g. British or American } \\
\text { English) for teaching and learning. }\end{array}$ & 148 & 1 & 5 & 3.69 & 1.074 \\
\hline 4. When I speak English, I want to sound like a native speaker. & 148 & 1 & 5 & 3.90 & 1.080 \\
\hline 5. When I speak English, I want to be identified clearly as Turkish. & 148 & 1 & 5 & 2.68 & 1.391 \\
\hline $\begin{array}{l}\text { 6. In international communication, intelligibility with accent is acceptable for } \\
\text { oral English. }\end{array}$ & 148 & 1 & 5 & 3.69 & 0.961 \\
\hline 7. The non-native speakers can also speak standardized English. & 148 & 1 & 5 & 3.65 & 0.917 \\
\hline 8. Most Turkish need English to communicate mainly with native speakers. & 146 & 1 & 5 & 3.51 & 1.233 \\
\hline $\begin{array}{l}\text { 9. Most Turkish citizens need English to communicate mainly with other non- } \\
\text { native speakers. }\end{array}$ & 147 & 1 & 5 & 3.62 & 1.029 \\
\hline 10. There are many standardized Englishes. & 145 & 1 & 5 & 3.34 & 0.996 \\
\hline 11. There will be a variety of English in Turkey one day. & 148 & 1 & 5 & 2.92 & 1.204 \\
\hline 12. Like Indian English, Turkey should have its own variety of English. & 148 & 1 & 5 & 2.52 & 1.301 \\
\hline
\end{tabular}


13. The variety of English in Turkey should have its own linguistic features at the levels of phonology, lexis, syntax and discourse.

$\begin{array}{lllll}146 & 1 & 5 & 2.47 & 1.271 \\ 148 & 1 & 5 & 2.66 & 1.158 \\ 148 & 1 & 5 & 3.22 & 1.187\end{array}$

English in addition to American and British English in college English.

Table 2 shows the basic descriptive statistics of 15 terms (items) used in the questionnaire. Among the items, the highest agreement was observed for item $2(\mathrm{M}=4.10, \mathrm{~s}=0.905)$. Item 2 is related to which varieties of English, British or American, is the common variety utilized in our textbooks. The second most favored items by the participants was item 4, which is related to whether the participants would like to sound like a native speaker. Most of the participants stated that they would like to sound like a native speaker $(M=3,90, s=1,080)$. In addition, participants also moderately believe that they have heard of world Englishes (M=3,76, s=1,149), that a native-speaker model of English should be adopted for teaching and learning purposes $(\mathrm{M}=3,69, \mathrm{~s}=1,074)$, and that for international communication, intelligibility for oral English is required $(\mathrm{M}=3,69, \mathrm{~s}=0,961)$. Also, a moderate number of the participants believe that non-native speakers can also speak standardized English ( $M=3,65, s=0,917)$.

The least favored items were item 12 and item 13, which are related to having one's own variety of English and whether the variety in Turkish should have its own linguistic features at the levels of phonology, lexis, syntax and discourse, respectively. Not many participants believe that there must be a separate variety in Turkey $(M=2,52, s=1,301)$ or, if so, that it should have its linguistic features at the levels of phonology, lexis, syntax and discourse $(M=2,47, s=1,271)$. The next least favored item was item $14(M=2,66, s=1,158)$. It is about whether the variety of English in Turkey can replace the existing teaching model. It seems that not many participants favor the use of a localized variety

The next part deals with the comparison of participants views in terms of their professions; instructors or students. Table 2 presents the results.

Table 3. T-test results regarding the profession

\begin{tabular}{|c|c|c|c|c|}
\hline Terms & Instructor & Student & Difference & $\begin{array}{l}\text { p- } \\
\text { value }\end{array}$ \\
\hline 1. I have heard of world Englishes. & 4.16 & 3.59 & 0.57 & $0.004 *$ \\
\hline $\begin{array}{l}\text { 2. British English and American English are the major varieties } \\
\text { of English used in our textbooks. }\end{array}$ & 4.33 & 4.01 & 0.32 & $0.054 *$ \\
\hline $\begin{array}{l}\text { 3. We should adopt a native-speaker model of English (e.g. } \\
\text { British or American English) for teaching and learning. }\end{array}$ & 3.27 & 3.87 & -0.60 & $0.001 *$ \\
\hline 4. When I speak English, I want to sound like a native speaker. & 3.61 & 4.02 & -0.41 & 0.066 \\
\hline $\begin{array}{l}\text { 5. When I speak English, I want to be identified clearly as } \\
\text { Turkish. }\end{array}$ & 1.91 & 3.00 & -1.09 & $0.000^{*}$ \\
\hline $\begin{array}{l}\text { 6. In international communication, intelligibility with accent is } \\
\text { acceptable for oral English. }\end{array}$ & 3.93 & 3.59 & 0.34 & 0.092 \\
\hline 7. The non-native speakers can also speak standardized English. & 3.93 & 3.53 & 0.40 & $0.037^{*}$ \\
\hline
\end{tabular}


8. Most Turkish need English to communicate mainly with 3.09

3.69

$-0.60$

$0.008 *$

native speakers.

9. Most Turkish citizens need English to communicate mainly 3.70

3.58

0.12

0.308

with other non-native speakers.

10. There are many standardized Englishes.

11. There will be a variety of English in Turkey one day.

$-0.44$

$0.011 *$

12. Like Indian English, Turkey should have its own variety of 2.30 English.

$2.62-0.32 \quad 0.138$

13. The variety of English in Turkey should have its own 2.05

$-0.60$

$0.005^{*}$

linguistic features at the levels of phonology, lexis, syntax and

discourse.

14. The variety of English in Turkey can replace the existing 2.00 teaching model.

15. Students should learn the characteristics of English and other 2.95 in college English.

*: significant at 0.05

It can be understood from Table 2 that instructors and students hold similar views on Items 4, 6, 9,12 and 15 ( $p>0.05$ ). This means that the participants do not vary in their views in terms of whether to sound a native speaker or not, whether international communication requires intelligibility or not, the fact that most Turkish speakers of English use it to communicate with non-native speakers, and whether Turkey should have its own English variety or not.

On the other hand, for most of the other items in the questionnaire, statistically significant differences were detected between two groups of professions. For items 1,2 and 7 ( $>>0.05$ ), instructors tended to agree more than students. It seems that instructors are more aware of world Englishes, which variety is mostly used in course books, and whether non-native speakers can speak a standardized variety. For items, 3, 5, 8, 10, 11, 13 and 14 (p>0.05), students have higher levels of agreement. It can be seen that students opt more for the use of a native-speaker model, want to be identified as Turkish when speaking English, and believe that Turkish people need English mainly to communicate with native speakers. In addition, students think that a variety of English is growing in Turkey, the variety of English in Turkey should have own linguistic features at all the levels such as phonology, lexis, and etc, and the variety of English in Turkey can replace the existing teaching model. It seems that students are more willing to accept the existence of a specific local variety and its use in for teaching and learning purposes. 
Table 4. T-test results regarding the gender

\begin{tabular}{|c|c|c|c|c|}
\hline Terms & Male & Female & Difference & $\begin{array}{l}\text { p- } \\
\text { value }\end{array}$ \\
\hline 1. I have heard of world Englishes. & 3.90 & 3.67 & 0.23 & 0.225 \\
\hline $\begin{array}{l}\text { 2. British English and American English are the major varieties of } \\
\text { English used in our textbooks. }\end{array}$ & 4.19 & 4.05 & 0.14 & 0.321 \\
\hline $\begin{array}{l}\text { 3. We should adopt a native-speaker model of English (e.g. British or } \\
\text { American English) for teaching and learning. }\end{array}$ & 3.53 & 3.80 & -0.27 & 0.097 \\
\hline 4. When I speak English, I want to sound like a native speaker. & 3.55 & 4.14 & -0.59 & $0.002 *$ \\
\hline 5. When I speak English, I want to be identified clearly as Turkish. & 2.33 & 2.91 & -0.58 & $0.015^{*}$ \\
\hline $\begin{array}{l}\text { 6. In international communication, intelligibility with accent is } \\
\text { acceptable for oral English. }\end{array}$ & 3.65 & 3.72 & -0.07 & 0.503 \\
\hline 7. The non-native speakers can also speak standardized English. & 3.57 & 3.70 & -0.13 & 0.278 \\
\hline $\begin{array}{l}\text { 8. Most Turkish need English to communicate mainly with native } \\
\text { speakers. }\end{array}$ & 3.33 & 3.64 & -0.31 & 0.148 \\
\hline $\begin{array}{l}\text { 9. Most Turkish citizens need English to communicate mainly with other } \\
\text { non-native speakers. }\end{array}$ & 3.47 & 3.72 & -0.25 & 0.224 \\
\hline 10. There are many standardized Englishes. & 3.36 & 3.34 & 0.02 & 0.731 \\
\hline 11. There will be a variety of English in Turkey one day. & 2.85 & 2.97 & -0.12 & 0.339 \\
\hline 12. Like Indian English, Turkey should have its own variety of English. & 2.32 & 2.66 & -0.34 & 0.086 \\
\hline $\begin{array}{l}\text { 13. The variety of English in Turkey should have its own linguistic } \\
\text { features at the levels of phonology, lexis, syntax and discourse. }\end{array}$ & 2.20 & 2.64 & -0.44 & $0.019 *$ \\
\hline $\begin{array}{l}\text { 14. The variety of English in Turkey can replace the existing teaching } \\
\text { model. }\end{array}$ & 2.52 & 2.76 & -0.24 & 0.337 \\
\hline $\begin{array}{l}\text { 15. Students should learn the characteristics of English and other } \\
\text { varieties of English in addition to American and British English in } \\
\text { college English. }\end{array}$ & 3.13 & 3.27 & -0.14 & 0.752 \\
\hline
\end{tabular}

*: significant at 0.05

Table 4 shows the results of the T-test which was run to compare mean scores pertaining to male and female participants. Based on the p-values, for most of the terms in questionnaire, males and females held similar views ( $p>0.05$ ). However, statistically significant differences were observed for items 4,5 and 13. Depending on the results, female participants seem to sound like a native speaker, be identified as a Turkish when speaking English, and believe that the variety of English in Turkey should have own linguistic features at all the levels such as phonology, lexis, and etc. 


\subsection{The analysis of the open-ended questions}

(1) What is your opinion about the native speaker and non-native speaker teacher dilemma (dichotomy). Which one is better for teaching/learning purposes?

For the first questions, $75 \%$ of the subjects (students / instructors), preferred native speakers to nonnative speakers as they wrote; "Native speakers are better." "I think a Native speaker is better for teaching/learning purposes." "As for me, a native speaker teacher is better than a non-native speaker teacher for teaching purposes." "I think native speaker is very important for pronunciation. He/she can pronounce the word effectively and clearly." "Both of them are needed because a non-native is important for showing similarities and differences between L1 and L2. A native is important for communication and pronunciation."

(2) What can you say about the knowledge of ELF (English as common Language) and EFL (English as a Foreign Language)?

For the Second Question; 55\% of the students made statements such as "It doesn't appear that English will be replaced by another language as lingua franca in the coming centuries and I think every human being should use English as a common language." "English is now the medium of instruction in every field. It is the tool of communication in almost every area, such as technology, science, music, etc." "Today English must be accepted as lingua franca." However, the other percentage of the students said, "Don't have much information." "I have no idea."

(3) Do you have any knowledge about Standard English or World Englishes (English as common Language)?

For the third question, $85 \%$ of the participants had mostly similar ideas "I think standard English is easier than the others so that at least standard English should be learned." "World English is the more beneficial." "Teaching of standard English is the best and ideal for students." "Standardised English is only spoken by native speakers." "Standard English is the correct form of English in terms of grammar, pronunciation and sentence structure." Which means that participants don't have enough information about WE.

\section{(4) What do you know about the cultural aspects in language teaching?}

Among participant responses for the fourth questions were; "Cultural aspects are very valuable for teaching." "Learners need to learn cultural differences if they want to master the language." "While teaching any foreign languages, it is important to take cultural aspects into consideration. However, it may cause the assimilation of the culture of the learners." "Cultural differences and the cultural background of students might be enormous obstacles in language teaching." "Culture is one of the determining aspects in the language learning process. Cultural discrepancy can cause difficulty in the language learning process and cultural affinity makes it easier to learn." Approximately 95\% percent of the students were on the side of culture in learning and teaching Language.

(5) Do you believe in the ownership of English Language in the world or should the ownership belong to any of the other languages?

For the fifth question, $50 \%$ of the participants expressed options such as "I could not understand the question clearly, but American/British English might be considered the HOME for the languages, which can be taken as the two norms." "I believe in the ownership of English Language in the world." "English 
has become an international language due to it is place in politics and history." However, the other half said; "Firstly, you should protect your own language and use it clearly. Then, you can own the other languages." "Ownership belongs to other languages."

\section{Discussion and conclusions}

English has become a universal phenomenon and its users come from diverse backgrounds, except for its native speakers. It can be said to have reached the status of a global language and it no longer assumes the traditional boundaries. Currently, there are several terms that are used when we talk about English in the world. Some of them are as follows: 'English as an international language (EIL)', 'English as a lingua franca (ELF)', 'English as a global language', 'English as a world language' and 'English as a medium of intercultural communication'.

There have only been a few studies (Deniz et al., 2016; Jenkins, 2017; Kırmızı \& Kırmız1, 2017; Matsuda, 2000; Mollin, 2006) which aimed to investigate the attitudes toward ELF and WEs. Therefore, this study aimed to learn about the attitudes of instructors and undergraduate students of English toward the notions of ELF and WEs. A two-part questionnaire was distributed to the instructor and student participants, and this research tried to shed light on the matter.

This research reflected some findings that might have some implications in English language teaching and learning from the point of view of participant instructors and the students which generally noted that British English and American English varieties of English were used in course books. The participants agreed on the idea that culture is important in language learning and therefore cultural elements should be included in textbooks. Mostly all the students were on the side of culture in learning and teaching. On the other hand, instructor participants in general said that they had heard the expression 'World English', but students generally had not heard of that term. Practically almost all the participants agreed with the idea that "standard English is easier than the others so that at least standard English should be learned". More than half of the student participants agreed on the idea that in the future there might be a variety of English in Turkey. There are not many significant differences between male and female participants apart from the outstanding fact that the female participants would prefer to speak like native speakers and to be understood by others.

In this respect, it can be understood that the differences between the items of ELF and WEs could not be understood by both students and instructors of English. While creating English teaching materials for secondary and higher education institutions, feedback from students and instructors should be considered in order to fulfil and respond the requirements of the contemporary globalised and changing world for the purposes of English Language teaching and learning. This recommendation should be considered in teacher/instructor in-service training services.

According to Deniz et al. (2016), as a result of the debate on ELF and World Englishes, new designs emerge that focus on the teaching of English as a lingua franca. Moreover, the debate on EFL also led to critical teacher education models. Matsuda (2012) makes the point that it would be a fallacy to assume that learners of English will only communicate with native speakers. As such, existing standardized models of langauge teaching may be redesigned to fit the concept of ELF. This means that nonstandardized forms or varieties of English should also be included in langauge teaching programs.

Furthermore, EIL implies that English is not connected to any nation or culture. This means that cultures of Inner Circle countries are not any more relevant in the teaching of English as the source cultural content. In such a case, the required methodology does not have to be dependent on a particular culture but rather needs to implement more locally-oriented cultural aspects. Widdowson (1994, p. 365) pointed out the following as regards the questions of ownership: 
The very fact that English is an international language means that no nation can have custody over it. ... It is a matter of considerable pride and satisfaction for native speakers of English that their language is an international means of communication. But the point is that it is only international to the extent that it is not their language. It is not a possession which they lease out to others, while still retaining the freehold. Other people actually own it.

In short, EIL paradigm can be taken as a linguistics and epistemological base through which researchers, scholars, and educators can do the following:

- revisit and reconsider their ways of conceptualizing English,

- re-assess their analytical tools and the approaches they adopt in the sociolinguistics of English and TESOL disciplines, and

- revise their pedagogical strategies for English language education in the light of the tremendous changes that English has undergone as a result of its global expansion in recent decades.

(Marlina, 2014: 4)

A number of researchers (Medgyes, 1994; Kramsch, 1998; Alptekin, 2002) hold the view that nonnative speakers play an important role in the teaching of English. According to Kramsch (1998), nonnative teachers may turn out to be more beneficial on the part of the learners since they have gone through a process of becoming a bilingual, and hence they can understand what it really means to learn a language. Moreover, Davies (1991) suggests that the distinction between native speaker and nonnative speaker compares to majority-minority relations, it is power driven, identity laden, and confidence affecting. Therefore, the native speaker and non-native speaker teacher dichotomy does not seem to be very fruitful. Results from the study are discussed, explained, and interpreted in the Discussion part. This part should explore the significance of the results of the study, not repeat them. A combined Results and Discussion section is often appropriate. Avoid extensive citations and discussion of published literature. The results are examined to determine whether the study's hypotheses were confirmed. This section allows you to offer your interpretation and explain the meaning of your results. If the findings are different from those that were predicted by the hypotheses, you have to provide tentative explanations for those discrepancies. For example, some common explanations for unexpected results in a study are that the sample size was too small, the study was too short, directions given to participants were not followed properly, the instruments were not valid or reliable, or the survey response rate was too low. Or, in some studies, one may speculate that the responses given by the participants were contrary to what was expected because people were dishonest in their responses or were reluctant to share certain sensitive information with others.

\section{References}

Alptekin. C. (2002). Towards intercultural communicative competence in ELT. ELT Journal, 56(1), 57-64. doi: 10.1093/elt/56.1.57

Ary, D., Jacobs, L. C., Sorensen C. \& Razavieh A. (2010). Introduction to research in education. CA: Nelson Education LTD.

Bamgbose, A. (1998). Torn between the norms: Innovations in world Englishes. World Englishes, 17(1), 1-14.

Bayyurt, Y. (2008). A lingua franca or an international language: The status of English in Turkey. ELF Forum, Helsinki, Finland. 
Bolton, K. (2004). World Englishes. In A. Davies \& C. Elder (Eds.), The handbook of applied linguistics (pp. 369-396). Oxford, England: Blackwell.

Brutt-Griffler, J. (2002). World Englishes: A study of its development. Clevedon: Multilingual Matters.

Canagarajah, A. S. (2005). Reclaiming the Local in Language Policy and Practice. Mahwah, NJ: Lawrence Erlbaum Publishers.

Collentine, J., Freed, B. F. (2004). Learning context and its effects on second language acquisition. Studies in Second Language Acquisition, 26, 153-171.

Cook, V. (2008). Second Language Learning and Language Teaching (4th ed), UK, Hodder Education.

Crystal, D. (2003). English as a Global Language. Cambridge: Cambridge University Press.

Davies, A. (1991). The native speaker in applied linguistics. Edinburgh, Scotland: Edinburgh University Press.

Deniz, E.B., Özkan,Y., \& Bayyurt, Y.(2016). English as a Lingua Franca: Reflections on ELF-Related Issues by PreService English Language Teachers in Turkey. The Reading Matrix: An International Online Journal, Volume 16, Number 2, September 2016.

Dewey, M. \& Patsko, L. (2017). ELF and Teacher Education [Chapter 35]. In Jenkins, J., Baker, W., \& Dewey, M. (Eds.). Handbook of English as a Lingua Franca. Published by Routledge.

Flowerdew, L.J. (2015). Adjusting pedagogically to an ELF world: An ESP perspective, In Y. Bayyurt and S. Akcan (eds.) Current Perspectives on Pedagogy for English as a Lingua Franca. Berlin: De Gruyter.

Firth, A. (1996). The discursive accomplishment of normality: On 'lingua franca' English and conversation analysis. Journal of Pragmatics, 26. 237-259.

Graddol, D. (2006). English next: Why global English may mean the end of 'English as a foreign language'? London: British Council.

He, D. (2015). University students' and teachers' perceptions of China English and world Englishes: Language attitudes and pedagogic implications, The Asian Journal of Applied Linguistics, 2(2), 6576.

House, J. (1999). Misunderstanding in intercultural communication: Interactions in English as a lingua franca and the myth of mutual intelligibility. In C. Gnutzmann (Ed.), Teaching and learning English as a global language (pp. 73-89). Tübingen: Stauffenburg.

Jenkins, J. (2003). World Englishes: A resource book for students. London \& New York: Routledge.

Jenkins, J. (2007). English as a Lingua Franca: Attitude and Identity. Oxford: Oxford University Press.

Jenkins, J. (2009). English as a Lingua Franca: interpretations and attitudes. World Englishes, 28 (2), 200-207.

Jenkins, J., Cogo, A., \& Dewey, M. (2011). Review of developments in research into English as a Lingua Franca. Language Teaching, 44(3), 281-315. doi:10.1017/S0261444811000115

Jenkins, J. (2017). ELF and WE: Competing or complementing paradigms?Eds. L. E.Ling and A. Pakir in World Englishes: Re-thinking Paradigms. Publisher: Routledge 
Inceçay, G., \& Akyel, A.S., (2014). Turkish EFL teachers' perceptions of English as a Lingua Franca. Turkish Online Journal of Qualitative Inquiry, 5(1), 1-12. doi: 10.17569/tojqi.84118

Kachru, B. B. (1985). Standards, Codification and Sociolinguistic Realism: The English Language in the Outer Circle. World Englishes, 20 (3), 365-381.

Kachru, B. B. (1992). The other tongue (2nd ed.). Urbana, Chicago: University of Illionis Press.

Kachru, B. (1996). Models for nonnative Englishes. In Braj B. Kachru (eds), The Other Tongue: English across Cultures. Delhi: Oxford University Press. (pp. 48-74).

Kırmızı, Ö. \& Kırmız1, G. D. (2017). "Language and Foreign/Second Language Concepts.” In A. Sarıçoban (Ed.), ELT Methodology. Ankara: Anı Yayıncılık.

Kinginger, C. (2008). Language learning in study abroad: Case studies of Americans in France. The Modern Language Journal, 92, 1-131

Kirkpatrick, A. (2007). World Englishes: Implications for international communication and English language teaching. Cambridge: Cambridge University Press.

Kirkpatrick, A. (2010). English as an Asian lingua franca and the multilingual model of ELT. Language Teaching, 44, 212-224.

Kramsch, C. (1998). The privilege of the intercultural speaker. In M. Byram \& M. Fleming (Eds.), Language learning in intercultural perspective: Approaches through drama and ethnography (pp. 16-31). Cambridge: Cambridge University Press.

Lowenberg, P. (2002). Assessing English proficiency in the expanding circle. World Englishes, 21, 431-35.

Mair, C. (2003). The Politics of English as a World Language. Amsterdam: Rodopi.

Marlina, R. (2014). The Pedagogy of English as an International Language (EIL): More Reflections and Dialogues, In Marlina, R. \& Giri, R.A.(eds.) The pedagogy of English as an international language: Perspectives from scholar, teachers, and students, Clayton: Springer.

Matsuda, A. (2000). Japanese attitudes toward English: A case study of high school students (Unpublished doctoral dissertation). Purdue University, West Lafayette, Indiana.

Matsuda, A. (2012). Teaching English as an international language: principles and practice. Clevedon, UK: Multilingual Matters.

McKay, S. L. (2002). Teaching English As an International Language: Rethinking Goals and Approaches. Oxford: Oxford UP.

Medgyes, P. (1994). Non-natives in ELT. London: Macmillan.

Mesthrie, R. and Bhatt, M., R. (2008). World Englishes: The Study of New Linguistic Varieties. UK: Cambridge University Press.

Mollin, S. (2006). Euro-English. Assessing Variety Status.Tübingen: Narr.

Paradowski, Michal B. (2008), Winds of Change in the English Language: Air of Peril for Native Speakers?, Novitas-Royal, 2 (1), 92-119.

Quirk, R. (1985). The English language in a global context. In R. Quirk \& H. G. Widdowson (Eds.), English in the world: Teaching and learning the language and the literatures (pp. 1-6). Cambridge, England: Cambridge University Press.

Quirk, R. (1990). Language varieties and standard language. English Today, 6(1), 3-10. 
Seidlhofer, B. (2004). Research perspectives on teaching English as a lingua franca. Annual Review of Applied Linguistics, 24. 209-239.

Seidlhofer, B. (2003). A concept of international English and related issues: From 'real English' to 'realistic English. Strasbourg: Council of Europe.

Seidlhofer, B. (2005). Key concepts in ELT: English as a lingua franca. ELT Journal, 59(4), 339-341.

Seidlhofer, B. (2011). Understanding English as a lingua franca. Oxford: Oxford University Press.

Sharifian, F. (2009). English as an International Language: Perspectives and Pedagogical Issues. Bristol: Multilingual Matters.

Tosuncuoğlu, İ. (2017). Non-Native \& Native English Teachers. Journal of History Culture and Art Research, 6(6), 634-638. doi:http://dx.doi.org/10.7596/taksad.v6i6.573

Widdowson, H. G. (1994). The ownership of English. TESOL Quarterly, 28(2), 337-389.

\section{Ortak dil olarak İngilizce ve dünya İngilizceleri hakkında üniversite öğrencileri ve öğretim görevlilerinin görüşleri}

\section{$\ddot{\mathbf{O} z}$}

İletişim dili olarak İngilizce'nin hızlı bir şekilde yayılması İngilizce'nin rolü ve ELF, WE, EIL, vb. gibi kavramlar hakkında geniş çaplı tartışmaları ortaya çıkarmıştır. Ortak dil olarak İngilizce veya Dünya İngilizce'leri paradigmaları arasında ayrım yapmak genellikle zordur ve buna ek olarak bu terimler genel olarak birbirinin yerine kullanılmaktadır. Öğretim görevlilerinin ve öğrencilerin ELF ve WE’e karşı algılarını ölçmek için hazırlanan bir sormaca bir devlet üniversitesinde uygulanmıştır. Sormaca, hem açık uçlu hem de çoktan seçmeli sorulardan oluşmaktadır. Çalışmanın katılımcıları, 44 öğretim görevlisi ve 104 İngiliz Dili ve Edebiyatı öğrencisidir. Öğretim görevlilerinin yaşları 23 ile 51 arasında ve öğrencilerin yaşları da 1825 arasında değişmektedir. Toplam katılımcı sayısı 148'dir. Katılımcıların çoğu, kendilerini "native speaker" olarak görmek istediklerini ve sesletim veya sözdizimi olarak farklı yerel İngilizce türlerinin verimli olmayacağını öne sürmektedirler.

Anahtar sözcükler: dünya İngilizceleri; Ortak dil olarak İngilizce; öğrenme; dil öğretimi

\section{AUTHOR BIODATA}

Dr. Özkan Kırmızı completed his B.A. at Hacettepe University, English Language Teaching Department. He also finished his M.A. and doctoral degree from the same department at Hacettepe University. He started working as an "assistant professors" in 2012 and became an Assoc. Prof. in March, 2018. Currently, he is working at Karabuk University English Language and Literature Department. His interest areas are L2 teacher development, preservice EFL teacher education, and intercultural communicative competence.

Dr. İrfan Tosuncuoğlu received his BA in 1992 from the English Language Teaching Department of the Faculty of Education. In 1998, he received a PhD from the English Language Teaching. Dr. Tosuncuoğlu has 
had more than 25 years of experience in the field of English Language Teaching and Administration in Turkey and other countries at both private and state educational institutions. His publications and research interests are in the field of Linguistics and English Language Teaching. 